\title{
Pengaruh Tingkat Kompresi Citra ALOS AVNIR2 terhadap Akurasi Hasil Transformasi Indeks Vegetasi dan Klasifikasi Penutup Lahan Wilayah Salatiga dan Ambarawa, Jawa Tengah
}

\section{Projo Danoedoro}

Laboratorium Penginderaan Jauh, Fakultas Geografi Universitas Gadjah Mada

Email koresponden:projo.danoedoro@geo.ugm.ac.id

Direvisi: 2019-11-19 Diterima: 2020-9-25

(C2020 Fakultas Geografi UGM dan Ikatan Geograf Indonesia (IGI)

\begin{abstract}
Abstrak Penggunaan teknik kompresi untuk menghemat ukuran penyimpanan citra digital telah banyak dijumpai dalam aplikasi keseharian. Di sisi lain, kompresi citra juga dapat memberikan konsekuensi berupa kehilangan detil data, yang akan berpengaruh pada integritas data, dan secara teoretis juga akan berpengaruh pada kualitas turunan data. Penelitian ini mengkaji pengaruh tingkat kompresi citra digital multispektral ALOS-AVNIR2 yang terdiri dari empat saluran dengan resolusi spasial 10 meter terhadap akurasi hasil transformasi indeks vegetasi dan klasifikasi penutup lahan untuk wilayah Salatiga-Ambarawa, Jawa Tengah. Citra dikompresi pada sembilan tingkat, yaitu dari tidak kehilangan detil sama sekali (100\%, atau sama dengan data asli) hingga 10\%, dengan interval 10\%. Indeks Vegetasi yang diterapkan meliputi NDVI, TVI dan MSARVI. Klasifikasi multispektral yang diujicobakan meliputi klasifikasi per-piksel dan klasifikasi berbasis objek. Hasil penelitian ini menunjukkan bahwa transformasi indeks vegetasi dan klasifikasi per-piksel mengalami penurunan akurasi secara drastis, sejalan dengan meningkatnya kompresi citra, sementara klasifikasi berbasis objek mengalami perubahan akurasi relatif lebih sedikit dibandingkan analisis perpiksel. Temuan penelitian ini menunjukkan bahwa penggunaan citra terkompresi sebagai masukan proses klasifikasi secara digital sebaiknya dihindari. Meskipun demikian, kalau pun terpaksa dilakukan karena masalah ketersediaan data, maka metode klasifikasi berbasis objeklah yang sebaiknya diterapkan; dan untuk klasifikasi per-piksel maka algoritma jarak minimum terhadap rerata-lah yang sebaiknya dipilih.
\end{abstract}

Kata kunci : kompresi citra, ALOS, indeks vegetasi, klasifikasi per-piksel, klasifikasi berbsis objek, pemetaan penutup lahan.

\begin{abstract}
The use of compression techniques for saving storage space of digital imagery has been commonly found in daily applications. On the other hand, image compression could also provide consequences of losing data details, which would affect data integrity and theoretically would also affect the quality of data derived. This study examined the effect of ALOS-AVNIR2 multispectal image compression level consisting of four channels with $10 \mathrm{~m}$ spatial resolution to the accuracies of vegetation index transformation and land cover classification for Salatiga and Ambarawa region, Central Java. This study compressed the image into nine levels, i.e. from lossless details (100\%, or equal to original data) up to $10 \%$ compression, at $10 \%$ intervals. The applied vegetation indices include NDVI, TVI and MSARVI. The multispectral classifications that were piloted include the per-pixel and object-based classification methods. The results of this study indicated that the vegetation index transformation and per-pixel classification have drastically decreased accuracies, in line with the increase in image compression; while the object-based classification has relatively more stable than per-pixel analysis. The findings of this study showed that the use of compressed imagery as an input to digital classification process should be avoided. However, even if it has to be done due to data availability issues, then object-based classification methods should be applied; and especially for per-pixel classification, the minimum distance to mean algorithm should be chosen.
\end{abstract}

Key words: image compression, ALOS, vegetation index, per-pixel classification, object-based classification, land-cover mapping

\section{PENDAHULUAN}

Penggunaan teknik kompresi untuk menghemat ukuran penyimpanan citra digital telah banyak dijumpai dalam aplikasi keseharian, baik di bidang penginderaan jauh maupun bidang grafis secara umum. Tidak sedikit perangkat lunak pengolah citra digital yang mampu menerima dan kemudian memproses data yang dikompresi. Google Earth juga merupakan contoh penyaji dan penyedia citra digital dalam bentuk yang telah terkompresi, di samping versi tak-terkompresinya. Di sisi lain, kompresi citra juga dapat memberikan kon- sekuensi berupa kehilangan detil data, khususnya untuk teknik yang bersifat lossy (Hussain et al., 2018). Kehilangan detil data berpengaruh pada integritas data, dan secara teoretis juga akan berpengaruh pada kualitas turunan data, terutama yang bertumpu pada analisis digital berbasis nilai piksel.

Walaupun kompresi citra merupakan cara yang lazim untuk menurunkan ukuran citra sehingga lebih mudah dibagikan secara digital, pada umumnya proses penginderaan 
jauh secara digital kurang memanfaatkannya sebagai masukan dalam analisisnya. Hal ini wajar, karena analisis citra digital menuntut kualitas citra yang bagus, di mana nilai piksel asli atau turunannya (misalnya nilai reflektansi) menjadi dasar pengenalan objek (Dewa dan Danoedoro, 2017; Hidayati et al., 2018a). Di sisi lain, meningkatnya aktivitas pemrosesan dan pertukaran data secara daring (online) juga menuntut ketersediaan data dalam ukuran relatif kecil, yang salah satunya dapat ditangani melalui proses kompresi citra.

Berpijak pada latar belakang tersebut maka dapat diangkat suatu masalah penelitian terkait dengan pengaruh kompresi citra terhadap kualitas hasil analisis yang dilakukan. Mengingat bahwa kompresi dapat dilakukan pada tingkat yang berbeda-beda tergantung tingkat kehilangan data yang dihasilkan, sementara itu analisis citra secara digital juga bisa dilakukan melalui proses klasifikasi dan transformasi spektral, maka diperlukan kajian pengaruh tingkat kompresi citra terhadap akurasi hasil transformasi indeks vegetasi dan klasifikasi multispektral.

Kompresi citra merupakan suatu upaya untuk menurunkan ukuran citra yang tersimpan di dalam media penyimanan, agar lebih mudah dibagikan bagi melalui penyalinan maupun melalui jaringan internet). Terdapat banyak metode untuk melakukan kompresi citra, yang secara garis besar dapat dikelompokkan menjadi dua kategori (Aronoff, 1990; Ghani et al., 2000; Chouwdury dan Khatun, 2012; Chang, 2017; Al-Janabi, 2015; Tan et al., 2019). Kategori pertama adalah jenis kompresi yang tidak menghilangkan detil informasi dari citra (lossless), namun hanya mengubah struktur penyimpanannya sehingga menjadi lebih efisien, misalnya run length encoding (RLE). Kategori kedua adalah jenis kompresi yang menghilangkan detil informasi pada citra (lossy), sehingga dihasilkan cira baru yang menempati ruang penyimpanan yang jauh lebih kecil namun sekaligus mengalami perubahan detil nilai di tiap pikselnya (Danoedoro, 2013).

Arti penting nilai piksel dalam proses ekstraksi informasi secara otomatis telah dijelaskan oleh banyak peneliti. Mather dan Koch (2011), Jensen (2015), dan Eastman (2019), misalnya, telah menekankan perlunya kalibrasi nilai piksel citra dari nilai asli atau digital number (DN) hingga ke nilai pantulan di permukaan (at-surface reflectance) dengan menggunakan berbagai metode. Sehubungan dengan hal itu, Danoedoro et al. (2015) meneliti pengaruh tingkat koreksi radiometrik terhadap akurasi hasil estimasi stok karbon di Semarang. Dewa dan Danoedoro (2017), Hidayati et al. (2018a), Umarhadi dan Danoedoro (2020) juga meneliti pengaruh penggunaan citra asli dan yang telah dikoreksi radiometri melalui berbagai transformasi indeks vegetasi untuk estimasi kerapatan vegetasi pada berbagai bentanglahan di wilayah Yogyakarta. Penelitian-penelitian tersebut menunjukkan bahwa perubahan nilai piksel berpengaruh terhadap hasil transformasi spektral dalam bentuk indeks maupun klasifikasi multispektral citra, yang ditunjukkan oleh nilai akurasi hasilnya.

Berkaitan dengan ekstraksi informasi berbasis nilai piksel, secara garis besar proses ekstraksi informasi dapat dilakukan melalui (a) indeks spektral termasuk indeks vegetasi, indeks urban dan indeks tanah (Hardjo et al., 2014; Sulistyo et al., 2017; Wisnawa et al., 2008; Danoedoro dan Zukhrufiyati, 2015; Hidayati et al., 2018b); dan (b) klasifikasi multispektral (Gao, 2010). Untuk klasifikasi multispektral, proses ekstraksi informasi dapat dilakukan dengan pendekatan per-piksel
(Jensen, 2015) maupun pendekatan berbasis objek atau OBIA (Navulur, 2007).

Berbeda halnya dengan interpretasi visual yang secara implisit dapat memasukan delapan unsur interpretasi dalam proses deteksi, identifikasi dan delineasi sekaligus, klasifikasi per piksel secara langsung hanya dapat menghasilkan informasi penutup lahan (Danoedoro, 2019; Danoedoro, et al. 2020), sementara klasifikasi berbasis objek dengan OBIA dalam batas tertentu dapat digunakan untuk pemetaan penggunaan lahan melalui serangkaian aturan yang lebih kompleks (Dragut et al., 2014; Eastman, 2019).

Secara spesifik, penelitian ini bertujuan untuk mengkaji pengaruh tingkat kompresi citra digital ALOS AVNIR2 terhadap akurasi hasil proses analisis transformasi indeks vegetasi dan klasifikasi multispektral, baik klasifikasi perpiksel maupun klasifikasi berbasis objek.

Penelitian ini menggunakan cira ALOS AVNIR2 yang meliput wilayah sekitar Ambarawa dan Salatiga, Jawa Tengah, dengan kenampakan penutup lahan yang bervariasi berupa vegetasi alami (padang rumput, enceng gondok, semak belukar, hutan), vegetasi budidaya (tanaman semusim seperti misalnya palawija dan padi, tanaman tahunan seperti

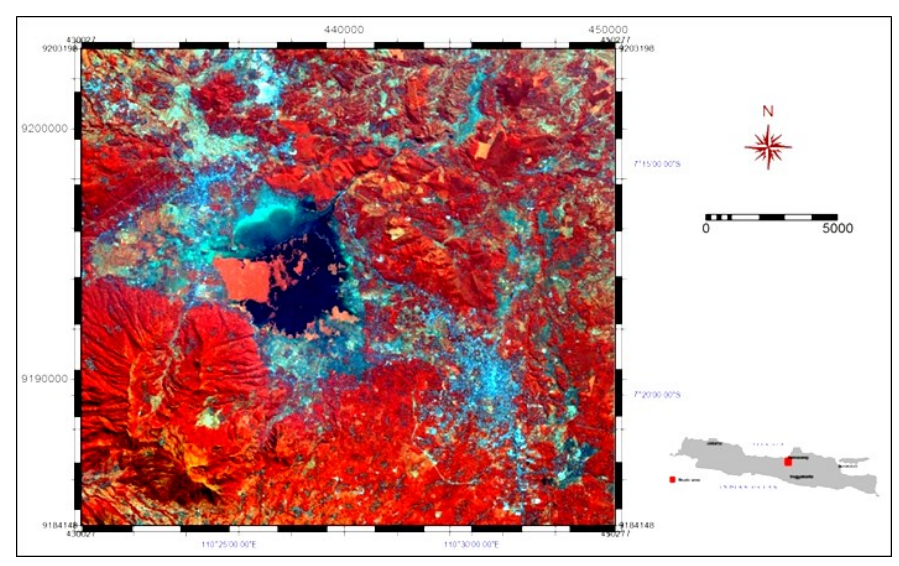

Gambar 1. Daerah penelitian yang tersaji dalam potingan citra ALOS AVNIR2 hasil perekamaan hasil perekaman 20 Juni 2009

misalnya jati, karet, kopi dan kakao), tubuh air berupa danau alami, serta bangunan. Kenampakan wilayah kajian tersaji pada Gambar 1, yang direkam oleh satelit ALOS AVNIR2.

\section{METODE PENELITIAN}

Secara garis besar, penelitian ini melibatkan tiga macam pemrosesan utama, yaitu (1) koreksi citra, baik secara geometrik maupun radiometrik, (2) kompresi citra berbagai tingkat, dan (3) analisis citra meliputi transformasi indeks vegetasi dan klasifikasi multispektral. Variabel utama yang dianalisis dalam penelitian ini meliputi tingkat kompresi citra dan tingkat akurasi hasil estimasi kerapatan dan hasil klasifikasi penutup lahan. Karena salah satu variabel dalam penelitian ini dimanipulasi sedemikian rupa pada berbagai tingkat kompresi, maka penelitian ini termasuk bersifat eksperimental. Secara ringkas, metode penelitian tersaji pada diagram alir berikut pada Gambar 2.

Bahan utama penelitian ini adalah citra multispektral ALOS-AVNIR2 hasil perekaman 20 Juni tahun 2009, dengan ukuran 1909 piksel x 2025 piksel, yang terdiri atas empat saluran spektral meliputi saluran biru $(0,42-0,50 \mu \mathrm{m})$, hijau $(0,52-0,60 \mu \mathrm{m})$, merah $(0,61-0,69 \mu \mathrm{m})$, dan inframerah 
dekat $(0,76-0.89 \mu \mathrm{m})$. Citra diperoleh melalui kerja sama antara UGM, LAPAN dan JAXA Jepang.

Alat utama dalam penelitian ini adalah seperangkat komputer dengan perangkat lunak pengolah citra ENVI untuk melakukan koreksi geometrik dan radiometrik kompresi citra, transformasi indeks vegetasi dan klasifikasi per-piksel, serta perangkat lunak pengolah citra dan SIG Idrisi/Terrset untuk segmentasi dan klasifikasi berbasis objek. Perangkat lunak ILWIS digunakan untuk mengatur tampilan dan tata letak hasil analisis citra.

Perlu ditekankan di sini bahwa penelitian ini tidak dimaksudkan untuk melakukan eksplorasi atas metode transformasi spektral berupa indeks vegetasi maupun metode klasifikasi citra. Oleh karena itu, dalam penelitian ini digunakan metode dan formula yang sudah lazim digunakan, karena titik beratnya adalah pengaruh pemrosesan berupa ekstraksi informasi otomatis terhadap citra yang mengalami kompresi.

\section{Cara Kerja}

Koreksi Geometrik

Citra ALOS AVNIR-2 dikoreksi geometrik dengan menggunakan peta rupabumi Indonesia (RBI) skala 1:25.000 wilayah yang sama sebagai acuan. Mengingat bahwa resolusi spasial citra ini adalah 10 meter, yang berarti secara ideal setara dengan citra tercetak skala 1:100.000 (Cao, 1992), maka peta RBI acuan tersebut sudah memadai.

\section{Koreksi/Kalibrasi Radiometrik Citra}

Untuk memproleh citra indeks vegetasi, citra asli dengan digital number (DN) dikonversi terlebih dahulu ke at-surface reflectance dalam persen, dengan menggunakan rumus berikut. Pertama, radiansi spektral $L_{\lambda}$ diturunkan dengan rumus

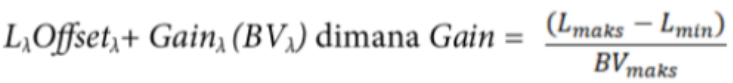

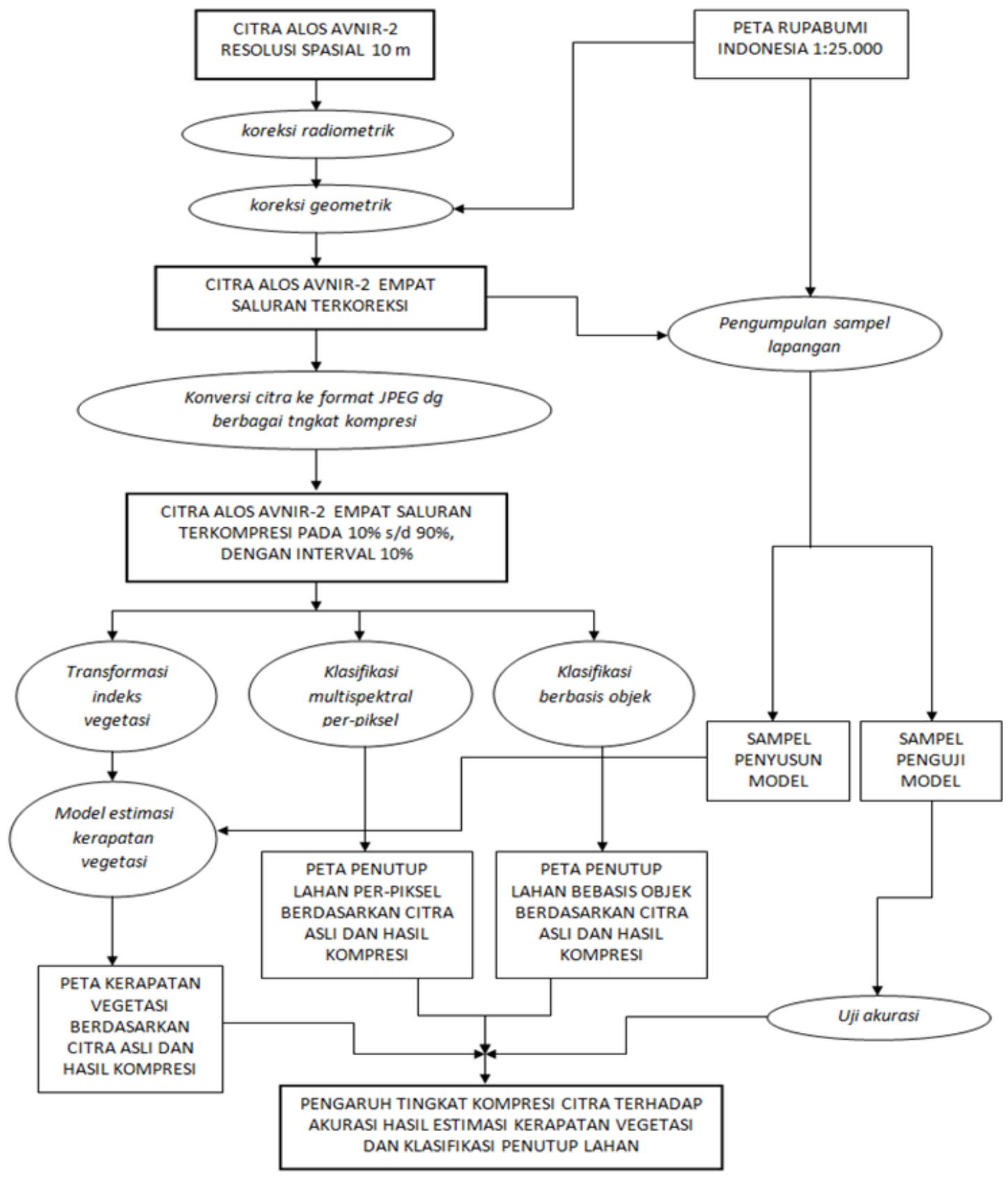

Gambar 2. Diagram alir penelitian 
Simbol $L_{\lambda}$ adalah nilai radiansi; BV adalah Brightness Value; dan Offset, Gain diperoleh dari perhitungan matematis antara radiansi spektral maksimum-minimum pada metadata citra. Kemudian nilai radiansi diubah menjadi nilai at-sensor reflectance berdasarkan persamaan:

$$
\rho_{P}=\frac{\pi \cdot L_{\mathrm{x}} \cdot d^{2}}{E \operatorname{SUN} N_{\mathrm{x}} \cdot \operatorname{Cos} \theta S}
$$

Pada rumus ini, nilai $d$ diperoleh dari rumus

$d=1-0,01674 \cos (0,9856(J D-4))$

di mana $\rho P$ adalah nilai at-sensor reflectance; $L_{\chi}$ adalah nilai radiansi $\left(\mathrm{Wm}^{-2} \mathrm{sr}^{-1} \mu \mathrm{m}^{-1}\right) ; \pi$ adalah konstanta dengan nilai 3,142857142857143; $d$ adalah jarak bumi-matahari (unit astronomi); $E S U N_{\chi}$ adalah nilai spektral iradiansi matahari $\left(\mathrm{Wm}^{-2} \mathrm{sr}^{-1} \mu \mathrm{m}^{-1}\right) ; \theta_{s}$ adalah sudut zenith matahari (dalam derajat); dan $J D$ adalah Julian Day. Kemudian koreksi ke at-surface reflectance dilakukan dengan menerapkan rumus berikut

$$
\begin{gathered}
\rho_{\text {terkoreksi }}=\rho_{P}-\text { bias } \\
\text { di mana bias }=\text { rerata }-(2 x \text { simpangan baku }) .
\end{gathered}
$$

Hasil akhir dari proses kalibrasi radiometrik ini adalah citra ALOS AVNIR-2 yang telah tersaji dalam bentuk atsurface reflectance, dengan nilai antara 0.0 sampai dengan 1.0; di mana nilai 1 mewakili nilai pantulan maksimal (100\%) yang pada dasarnya hampir mungkin tercapai.

\section{Kompresi Citra}

Untuk memperoleh citra pada berbagai tingkat kompresi, dilakukan proses kompresi citra asli ke format JPEG (Joint Photographic Expert Group) ke sembilan tingkat, yaitu kompresi ke 90\%, 80\%, 70\% dan seterusnya hingga kompresi ke $10 \%$, dengan interval $10 \%$. Semakin kecil angka tingkat kompresi, semakin tinggi tingkat kompresinya, karena ukuran citra hasil kompresi semakin kecil. Efek utama dari kompresi ini adalah menyusutnya ukuran citra (dalam kilobyte atau $\mathrm{KB}$ ), yang disebabkan oleh menyusutnya detil nilai yang berbeda-beda pada tiap piksel. Proses kompresi menyebabkan citra baru kehilangan detil, dan kelompok-kelompok piksel yang berdekatan, baik secara spasial maupun spektral, akan mempunyai nilai baru yang saling berdekatan. Kompresi citra ini diterapkan pada citra asli yang belum dikoreksi radiometrik maupun yang telah dikalibrasi ke at-surface reflectance.

Karena keterbatasan dalam ketersediaan perangkat lunak yang ada, maka kompresi data asli dilakukan dengan menggunakan format JPEG standar (*.JPG) dan bukan JPEG2000 (*.JP2). Memang kelebihan penggunaan format JPEG2000 adalah dimungkinkannya penyimpanan citra dengan jumlah saluran lebih dari tiga, sehingga cocok untuk menangani citra penginderaan jauh yang mempunyai lebih dari tiga saluran. Meskipun demikian, perangkat lunak yang tersedia (ENVI) hanya mampu mengkonversi citra asli ke tiga macam data JP2 dengan tingkat kompresi yang berbeda, yaitu lossless (tidak kehilangan detil), low compression (kompresi rendah, detil yang hilang tidak banyak), dan high compression (kompresi tinggi, detil yang hilang sangat banyak), tanpa penjelasan mendalam tentang berapa persen low dan high compressison tersebut

Dengan memperhatikan keterbatasan tersebut, maka penelitian ini melakukan kompresi untuk setiap saluran
ALOS AVNIR-2 secara individu ke format JPEG (*.JPG), yang dapat diatur tingkat kompresinya dengan interval $10 \%$. Setelah itu, data setiap saluran individual hasil kompresi dikompilasi kembali ke dalam satu dataset dengan format BIL (band interleaved by line), namun dengan karakteristik perubahan nilai piksel sesuai dengan standar JPG. Dengan cara ini maka dapat dihasilkan citra asli dan yang telah terkompresi pada berbagai tingkat dengan format JPG.

\section{Transformasi Indeks Vegetasi dan Estimasi Kerapatan Vegetasi}

Transformasi indeks vegetasi diterapkan pada citra yang telah terkoreksi radiometric hingga at surface reflectance, baik pada citra asli maupun hasil kompresi pada berbagai tingkat. Transformasi indeks vegetasi yang diterapkan pada penelitian ini meliputi NDVI, TVI dan MSARVI, yang masing-masing menggunakan rumus sebagai berikut (Danoedoro et al., 2015):

$$
\begin{aligned}
& \text { NDVI }=\frac{(\rho \text { Inframerah Dekat }-\rho \text { Merah })}{(\rho \text { Inframerah Dekat }+\rho \text { Merah })} \\
& \text { TVI }=0,5(120(\rho \text { Inframerah Dekat }-\rho \text { Hijau }))-200(\text { Merah }-\rho \text { Hijau }) \\
& \text { MSARVI }=\frac{2 \rho \text { Infra. Dekat }+1-\sqrt{\left[(2 \rho \text { Infra. Dekat }+1)^{2}-\gamma(\rho \text { Infra. Dekat }-\rho r b)\right]}}{2}
\end{aligned}
$$

\section{Klasifikasi Multispektral untuk Penutup Lahan}

Klasifikasi multispektral dilakukan dengan dua macam cara, yaitu klasifikasi per-piksel dan klasifikasi berbasis objek. Untuk klasifikasi per-piksel, digunakan tiga macam algoritma klasifikasi, yaitu (a) nearest distance to mean, (b) parallel-epiped, dan (c) maximum likelihood. Menurut Gao (2010), algoritma minimum distance to mean menggunakan jarak euklidian antara piksel target dengan nilai rerata sampel dalam ruang spektral untuk menentukan keanggotaan suatu piksel; sementara algoritma parallelepiped menggunakan kriteria ukuran kotak multidimensi yang dibentuk oleh nilai simpangan baku setiap sampel dikalikan dengan suatu nilai faktor pengali, sehingga piksel target dievaluasi keanggotaannya dengan memperhatikan vektor piksel tersebut, apakah di dalam kelas tertentu, atau di luar semua kelas (tak terklasifikasi). Untuk maximum likelihood, pemberian label keanggotaan suat piksel target dilakukan dengan memperhatikan bentuk dan orientasi masing-masing sampel dalam ruang spektral, dengan ukuran kontur ekuiprobabilitas (Lillesand et al., 2014).

\section{Klasifikasi Berbasis Objek}

Klasifkasi berbasis objek sederhana dilakukan dengan mengacu pada metode Eastman (2019). Metode ini mencakup dua langkah aktivitas, yaitu proses segmentasi dan klasifikasi itu sendiri. Proses segmentasi dilakukan berdasarkan surface image yang diturunkan dari nilai variansi setiap saluran dengan ukuran jendela bergerak $3 \times 3$. Proses ini memerlukan masukan berupa bobot setiap saluran masukan, bobot faktor piksel-piksel kandidat segmen (objek) berupa rerata dan variansi.

Setelah itu program membentuk semacam 'daerah tangkapan' (watershed) dengan analogi seperti pada citra DEM, sehingga piksel-piksel yang berdekatan dan punya kemiripan akan mempunyai nilai variansi rendah dan dikumpulkan menjadi satu segmen. Proses penggabungan segmen dengan kriteria toleransi kemiripan (similarity 
tolerance) akan dilakukan secara interaktif, dengan memperhatikan nilai rerata setiap segmen dan selisih standar deviasi.

Sekali segmen-segmen ini terbentuk maka dapat dilakukan proses pengambilan sampel, di mana objek berupa segmen menggantikan poligon region of interest (ROI) dalam klasifikasi per piksel. Parameter statistik untuk sampel dihitung per objek segmen, dan kemudian menjadi dasar komputasi klasifikasi per-piksel. Hasil langsung dari klasifikasi per piksel ini adalah citra terklasifikasi berbasis piksel, yang kemudian ditumpangsusunkan dengan poligon-poligon objek hasil segmentasi, untuk menentukan atribut setiap segmen melalui aturan label piksel mayoritas di dalamnya.

\section{Pengujian Akurasi}

Uji akurasi dalam penelitian ini mengacu ke data lapangan yang didukung oleh citra resolusi spasial tinggi yang tersedia pada Google Earth. Pengujian dilakukan dengan kalkulasi standard error of estimate (SE) dan matriks kesalahan. SE diterapkan pada hasil estimasi kerapatan berbasis indeks vegetasi, sementara matriks kesalahan diterapkan pada citra hasil klasifikasi per piksel mapun berbasis objek. Untuk SE digunakan rumus berikut:

$$
S E=\sqrt{\frac{\sum\left(y_{i}-y_{i}^{j}\right)^{2}}{(n-2)}}
$$

di mana $y$ adalah nilai acuan lapangan dan $y^{\prime}$ adalah nilai hasil pemodelan untuk setiap sampel, sementara $n$ adalah jumlah sampel. Perhitungan akurasi dalam persen untuk sejumlah $\mathrm{n}$ pasangan data rasio/interval menggunakan rumus sebagai $A=100-D$, di mana $D$ adalah standar penyimpangan nilai estimasi dalam persen untuk seluruh data, dengan rumus berikut:

$$
D=\sqrt{\frac{\sum\left(d_{i}-d_{i}^{b}\right)^{2}}{[n-2)}} d=100 *\left(\frac{y_{i}-\left|y_{i}-y_{i}^{b}\right|}{y_{i}}\right)
$$

Matriks kesalahan mengikuti formulasi yang dijelaskan oleh Lillesand et al. (2014) dan Jensen (2015), di mana pikselpiksel hasil klasifikasi ditumpangsusunkan dengan semua poligon penguji untuk menghasilkan nilai omisi dan komisi, akurasi total, serta akurasi pengguna maupun akurasi produsen. Penelitian ini menekankan nilai akurasi total sebagai kajian utama.

\section{HASIL DAN PEMBAHASAN}

Hasil kompresi dari 90\% hingga 10\% tersaji pada Tabel 1. Terlihat bahwa seiring dengan peningkatan kompresi, ukuran citra menyusut drastis. Kompresi sebanyak 10\% mengakibatkan penyusutan ukuran penyimpanan citra menjadi kurang dari 50\% ukuran penyimpanan citra asli, sementara kompresi sebanyak $90 \%$ mengakibatkan penyusutan
Tabel 1. Perubahan ukuran citra ALOS AVNIR-2 daerah penelitian ketika dilakukan kompresi ke format JPEG

\begin{tabular}{ccc}
\hline $\begin{array}{c}\text { Tingkat } \\
\text { Kompresi (\%) }\end{array}$ & $\begin{array}{c}\text { Dimensi Citra } \\
\text { (baris } \times \text { kolom) }\end{array}$ & $\begin{array}{c}\text { Ukuran } \\
\text { penyimpanan } \\
(\mathrm{KB})\end{array}$ \\
\hline $\begin{array}{c}\text { Tanpa } \\
\text { kompresi } \\
10 \%\end{array}$ & $1909 \times 2025$ & 15,101 \\
$20 \%$ & $1909 \times 2025$ & 7,002 \\
$30 \%$ & $1909 \times 2025 \times 2025$ & 5,668 \\
$40 \%$ & $1909 \times 2025$ & 4,155 \\
$50 \%$ & $1909 \times 2025$ & 3,402 \\
$60 \%$ & $1909 \times 2025$ & 2,842 \\
$70 \%$ & $1909 \times 2025$ & 2,204 \\
$80 \%$ & $1909 \times 2025$ & 1,698 \\
$90 \%$ & $1909 \times 2025$ & 1,213 \\
\hline & 1956 \\
\hline
\end{tabular}

ukuran penyimpanan hingga $6 \%$ dari ukuran penyimpan citra asli. Semakin tinggi tingkat kompresi, semakin banyak pula informasi yang hilang.

Gambar 3 menunjukkan contoh citra yang (a) asli, (b) terkompresi tanpa kehilangan detil (kualitas data sama dengan citra asli, lossless), (c) terkompresi 30\% (menjadi 70\%) dan (d) terkompresi 90\% (menjadi 10\%.). Gambar ini melengkapi Tabel 1, sehingga jelas terlihat bahwa semakin kecil ukuran penyimpanan, semakin banyak detil kenampakan citra yang hilang.

\section{Transformasi Indeks Vegetasi dan Estimasi Kerapatan Vegetasi}

Indeks vegetasi dalam bentuk NDVI, TVI dan MSARVI diterapkan pada citra asli maupun citra terkompresi. Efek kompresi pada penggunaan ketiga indeks vegetasi tersebut secara visual relatif sama, meskipun analisis per-piksel secara lebih rinci menunjukkan adanya perbedaan. Seperti tersaji pada Gambar 4, citra NDVI digunakan untuk mewakili kenampakan citra asli dan citra yang terkompresi ke 50\% dan ke $10 \%$, yang telah mengalami proses transformasi spektral. Pada citra asli, kenampakan detil vegetasi dan bukan vegetasi terlihat jelas dengan teksturnya, sementara pada citra

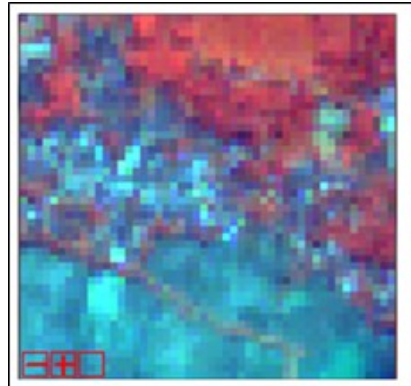

A.CITRAASU

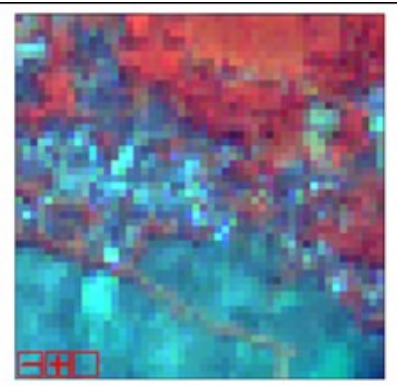

B.CITRA TERKOMPRESI LOSSLESS

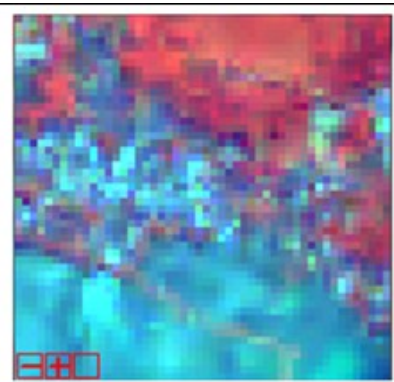

C.CITRA TERKOMPRESI KE 70\%

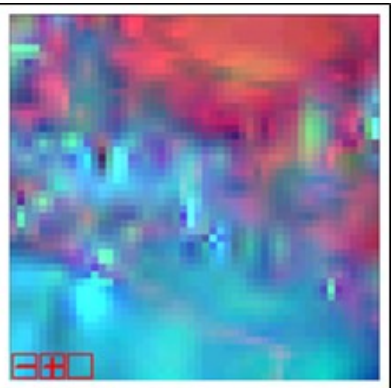

D.CITRA TERKOMPRESI KE $30 \%$

Gambar 3. Potongan kenampakan citra asli yang dibandingkan dengan citra hasil kompresi, disajikan dengan perbesaran empat kali agar detil tiap piksel terlihat jelas. 
terkompresi ke 50\%, generalisasi telah mengubah banyak variasi kecerahan yang ada, sehingga objek yang sebelumnya cerah (mewakili vegetasi rapat) bisa berubah menjadi gelap, begitu pula sebaliknya. Pada kompresi ke 10\%, perubahan ini terlihat semakin parah.

Data berupa nilai NDVI pada sampel sebanyak 20 buah kemudian dikorelasikan dengan nilai kerapatan di lapangan. Disamping itu, 20 sampel penguji juga dikumpulkan selama kerja lapangan. Survei lapangan untuk pengukuran kerapatan vegetasi penyusun model di lapangan dilakukan secara terpisah dari survei lapangan penguji akurasi. Baik data kerapatan penyusun model maupun penguji akurasi di lapangan dikumpulkan melalui strategi pengambilan sampel acak terstratifikasi, di mana kenampakan kerapatan pada citra menjadi dasar pengelompokan strata. Dengan demikian, terdapat 10 pasangan data kerapatan - NDVI yang mewakili 10 jenis citra NDVI, meliputi yang asli dan sembilan tingkat kompresi. Contoh potongan dari peta kerapatan vegetasi berbasis NDVI tersaji di Gambar 5, dengan liputan dan tingkat kompresi yang sama dengan contoh pada Gambar 4. Dari masing-masing pasangan kemudian dilakukan analisis korelasi dan regresi, serta disusun 10 peta kerapatan vegetasi, yang masing-masing kemudian diuji akurasinya meng-gunakan 20 data independen. Hasil analisis berupa SE disajikan pada Gambar 5, sementara nilai akurasi estimasi dalam persen disajikan pada Gambar 6.

Gambar 6 dan 7 menjelaskan bahwa ketiga macam indeks vegetasi tidak menunjukkan kepekaan yang jauh berbeda, namun ketiganya juga sama-sama mengalami perubahan akurasi yang drastis dalam aplikasi yang sama, ketika diterapkan pada data yang telah dikompresi. Nilai absolut penurunan dan kecenderungan penurunan akurasi ketiganya pun relatif sama. Hal ini bisa terjadi karena perubahan nilai indeks vegetasi terjadi secara nyata pada berbagai lokasi sebagai akibat dari kompresi citra yang bersifat lossy, yang merusak nilai piksel asli. Perubahan begitu drastis sehingga objek yang seharusnya vegetasi (indeks vegetasi tinggi, cerah) pada citra asli pun bisa berubah menjadi objek bukan vegetasi (indeks vegetasi sangat rendah, gelap) pada hasil kompresi, karena detil yang hilang.

\section{Klasifikasi Multispektral Per-piksel}

Klasifikasi multispektral menggunakan algoritma maximum likelihood, paralell-epiped, dan minimum distance to mean diterapkan pada sub-dataset asli dan yang telah dikompresi. Pada tahap pertama, satu set poligon dalam bentuk region of interest (ROI) dipilih sebagai sampel. Komputasi keterpisahan antar-sampel dilakukan dengan menggunakan rumus Transformed Divergence dan JeffriesMatushita (Gao, 2010; Jensen, 2015) untuk setiap ROI baru yang diambil, sehingga pemisahan antara sampel tetap maksimal. Ketika ROI ditetapkan, statistik sampel berdasarkan masing-masing sub-dataset diperoleh, untuk digunakan sebagai masukan proses klasifikasi. ROI yang sama digunakan dalam sub-dataset asli dan terkompresi, untuk menjaga konsistensi area sampel. Namun, isi informasi statistik dari masing-masing sub-dataset berbeda, bergantung pada nilai piksel baru yang terbentuk sebagai hasil proses kompresi.

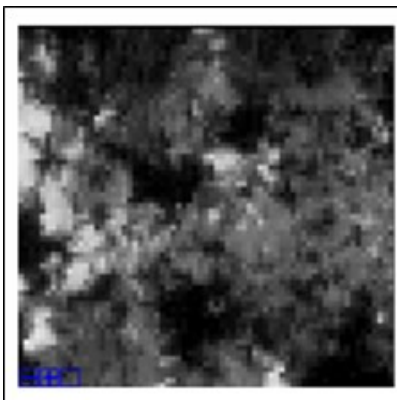

A. CITRA NDVI ASU

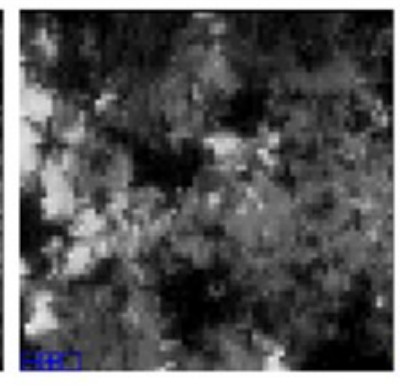

B. TERKOMPRESI LOSSLESS

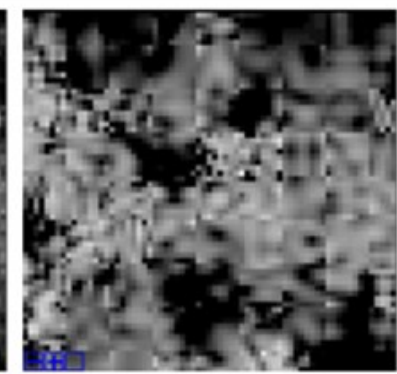

C. TERKOMPRESI KE $50 \%$

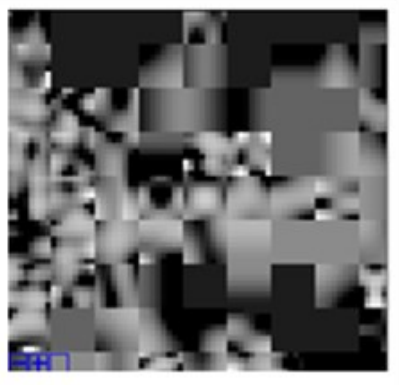

D. TERKOMPRESI KE $10 \%$

Gambar 4. Citra NDVI pada berbagai tingkat pengaturan kompresi, yang menggambarkan wilayah yang sama namun diperbesar empat kali. Terlihat adanya perubahan kecerahan (yang berarti perubahan representasi kerapatan vegetasi sebagai akibat dari proses kompresi.

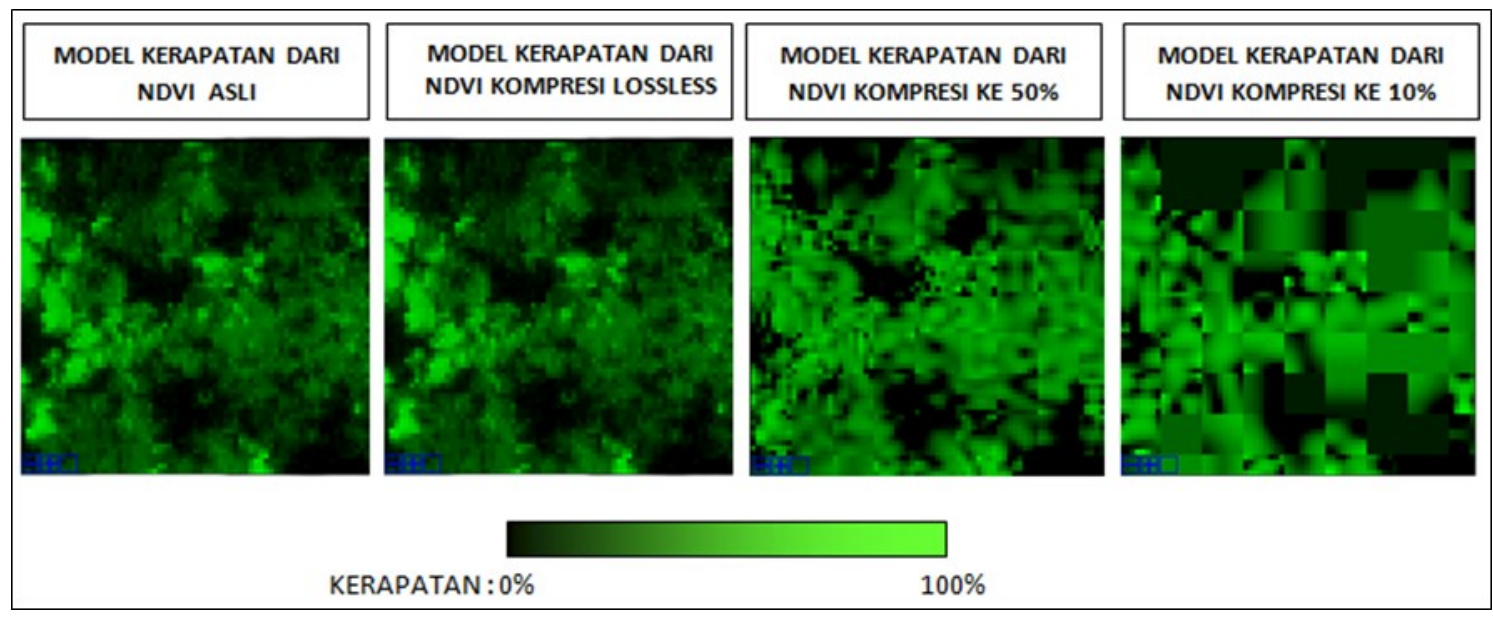

Gambar 5. Perbandingan distribusi kerapatan vegetasi hasil pemodelan dengan indeks vegetasi untuk citra asli, terkompresi lossless, terkompresi ke 50\% dan terkompresi ke $10 \%$ 
Ketika diterapkan pada citra asli (tidak ada kompresi), algoritma maximum likelihood menunjukkan hasil terbaik, meskipun hasil uji akurasi peta penutup lahan tentatif hanya mencapai akurasi keseluruhan 50,82\%. Sebaliknya, algoritma parallel-epiped dan minimum distance to mean menghasilkan tingkat akurasi yang lebih rendah, yaitu masing-masing sebesar $11,13 \%$ dan $37,78 \%$. Nilai akurasi yang relatif rendah untuk hasil klasifikasi secara langsng ini wajar, meskipun ternyata ALOS AVNIR-2 memberikan hasil yang lebih buruk dibandingkan hasil klasifikasi dengan citra Landsat ETM+ untuk wilayah yang hampir sama, yang mencapai lebih dari 70\% (Danoedoro, 2006).

Ketika proses pengabungan kelas-kelas tentatif dilakukan untuk memperoleh kelas-kelas penutup lahan akhir, akurasi keseluruhan untuk citra asli yang tidak dikompresi dan diklasifikasi dengan maximum likelihood meningkat drastis menjadi $79,48 \%$, sementara penggabungan kelas untuk hasil klasifikasi dengan parallel-epiped dan minimum distance to mean memberikan nilai akurasi keseluruhan berturut-turut $26,33 \%$ dan $58 \%$. Gambar 8 menyajikan contoh hasil klasifikasi dengan minimum distance to mean.

Gambar 9 menunjukkan bahwa secara umum proses kompresi akan menghasilkan data yang menurun kualitasnya, apabila dijadikan masukan dalam klasifikasi perpiksel. Di antara tiga macam algoritma klasifikasi multispektral per-piksel, algoritma maximum likelihood menghasilkan penurunan kualitas produk klasifikasi yang paling parah dibandingkan dengan hasil yang diperoleh dari data asli. Meskipun demikian, terdapat penyimpangan hasil yang ditunjukkan oleh algoritma minimum distance to mean, di mana citra yang terkompresi justru menunjukkan peningkatan akurasi klasifikasi dibandingkan citra asli. Dengan kata lain, klasifikasi dengan algoritma minimum distance to mean menunjukkan konsistensi yang paling baik dibandingkan algoritma klasifikasi per-piksel dengan maximum likelihood dan parallel-epiped, meskipun efek penggabungan kelas yang terjadi justru tidak sedrastis dua algoritma yang lain.

Penjelasan atas penyimpangan ini bisa dikaitkan dengan kriteria pemberian label kelas atau atribut menurut masingmasing algoritma serta proses kompresi itu sendiri. Pada dasarnya kompresi dengan format JPEG menggeneralisasi kenampakan objek dalam ukuran blok tertentu (Chang, 2017), dan hasil generalisasi ini diwujudkan dalam perubahan nilai yang cenderung mendekati rerata. Oleh karena itu, efek yang ditimbulkan antara lain adalah kenampakan kabur dengan batas antar objek (secara visual) yang tidak jelas, yaitu dengan kesan tambahan berupa resolusi spasial efektif yang lebih rendah. Algoritma parallel-epiped menggunakan kriteria nilai rerata dan simpangan baku, sehingga ukuran kotak (box) sampel cenderung kecil, namun sekaligus memuat inkosistensi nilai piksel untuk jenis objek yang sama pada susunan ketetanggaan yang berbeda dengan objek lain. Inkonsistensi ini yang menyebabkan nilai akurasi algoritma parallel-epiped menjadi sangat rendah. Di sisi lain, algoritma maximum likelihood menuntut persyaratan kurva normal untuk setiap sampelnya, dan syarat ini tidak bisa dipenuhi oleh objekobjek yang sama pada citra terkompresi, karena efek ketetanggaan yang sama, yang merusak nilai piksel asli.

Perbandingan perubahan nilai standard error of estimate

(SE) antara beberapa indeks vegetasi untuk berbagai tingkat kompresi citra ALOS AVNIR-2

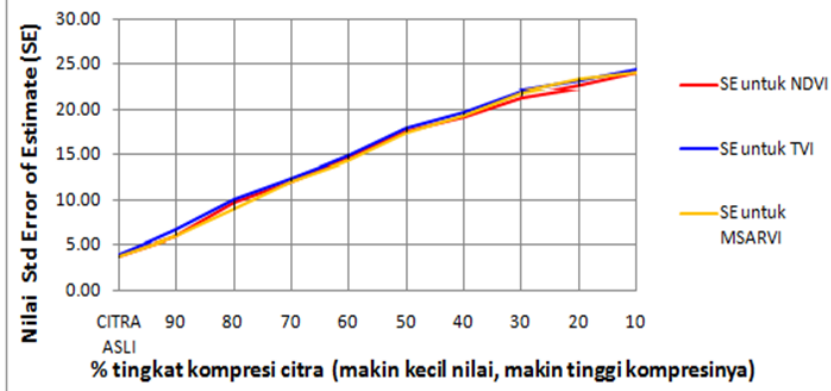

Gambar 6. Perubahan nilai SE untuk estimasi kerapatan vegetasi dengan tiga macam indeks vegetasi, sejalan dengan perubahan tingkat kompresi citra ALOS AVNIR-2

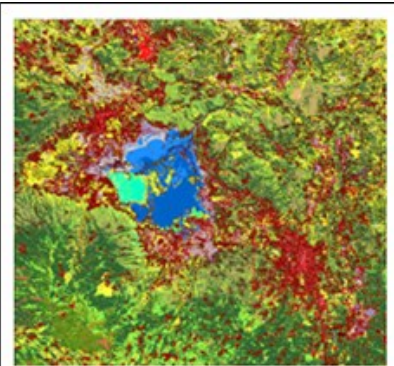

A.MINIMUM DIST, CITRA ASU

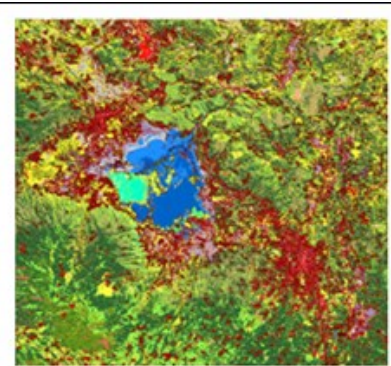

B. MINIMUM DISTANCE, KOMPRESI LOSSLESS

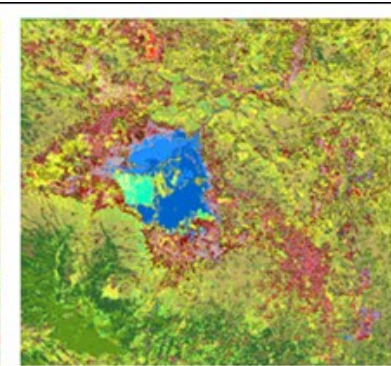

C. MINIMUM DISTANCE, KOMPRESI KE-50\%

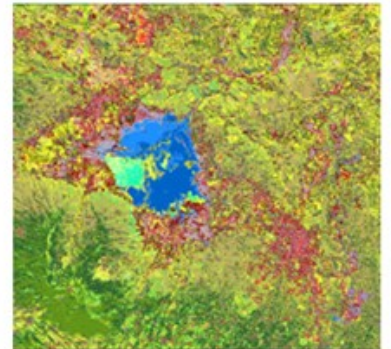

D. MINIMUM DISTANCE, KOMPRESI KE-10\%

Gambar 8. Contoh hasil klasifikasi multispektral per-piksel dengan algoritma minimum distance to mean pada potongan citra asli dan berbagai citra terkompresi 
Hasil yang sebaliknya terjadi pada klasifikasi dengan algoritma minimum distance to mean. Algoritma yang sangat sederhana ini hanya mengandalkan jarak spektral minimum piksel target terhadap nilai rerata sampel dalam ruang spektral (dengan perhitungan jarak euklidian), sehingga perubahan nilai piksel akibat proses kompresi tidak terlalu berpengaruh, sejauh kriteria nilai ambang jarak maksimum -seperti yang digunakan dalam penelitian ini tidak digunakan.

\section{Klasifikasi berbasis Objek}

Pendekatan OBIA dalam hal klasifikasi berbasis objek dimulai dengan segmentasi citra. Dengan menggunakan IDRISI/Terrset, segmentasi citra memperhitungkan beberapa parameter yang telah disebutkan sebelumnya. Untuk daerah Salatiga dan Ambarawa dengan jumlah saluran spektral yang sama, ditemukan bahwa similarity tolerance memainkan peran yang paling penting dalam menentukan segmen atau wilayah. Pada proses ini, hasil segmentasi ditumpangsusunkan dengan citra komposit warna sebagai dasar evaluasi visual. Upaya dengan mencoba berbagai skenario pada berbagai toleransi kesamaaan menemukan bahwa nilai antara 15, 30, 45 dan 60 adalah nilai yang paling efektif untuk menentukan daerah sebelum proses pengambilan sampel berbasis segmen dan klasifikasi berbasis objek. Parameter ini diterapkan pada sub-dataset ALOSAVNIR2 asli (tidak terkompresi), dan juga sub-dataset terkompresi yang berasal dari kompresi ke 90 sampai dengan ke 10\%. Gambar 10 menunjukkan perbedaan antara hasil segmentasi citra asli dan beberapa sub-dataset citra terkompresi. Terlihat bahwa perubahan segmen yang terjadi tidak terlalu besar, dibandingkan dengan perubahan nilai indeks vegetasi.

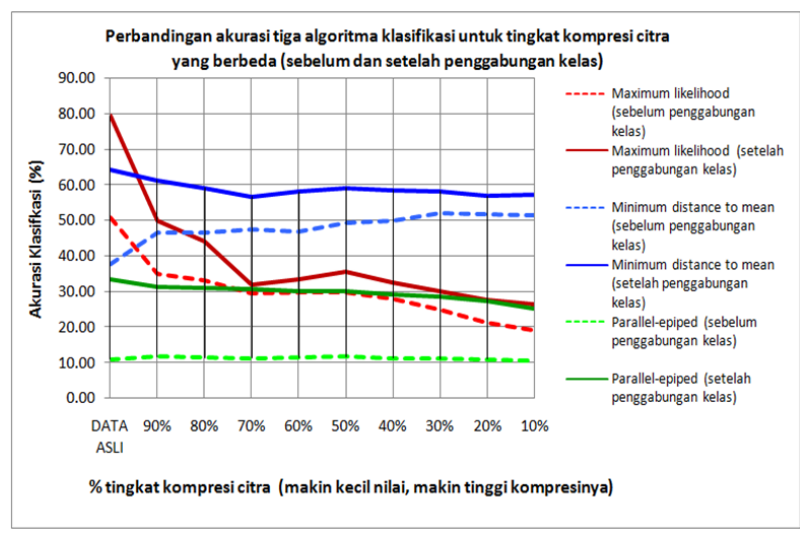

Gambar 9. Perbandingan akurasi tiga algoritma klasifikasi per-piksel

Segmen-segmen ini kemudian digunakan sebagai dasar pengambilan sampel. Hasil segmentasi menyediakan peta poligon, di mana poligon terpilih menjadi sampel seperti halnya ROI pada klasifikasis per piksel. Poligon sampel terpilih kemudian diproses untuk mengembangkan data ciriciri spektral (spectral signatures) sampel. Sebelum eksekusi klasifikasi berbasis objek, ciri-ciri spektral poligon sampel digunakan untuk menghasilkan klasifikasi per-piksel. Setelah itu, hasil klasifikasi per-piksel digabungkan dengan hasil segmentasi untuk menetapkan kelas akhir untuk setiap segmen. Pada tahap ini, aturan mayoritas diterapkan.

Dengan enam sub-dataset yang terdiri dari citra asli dan cira terkompresi pada berbagai tingkat, klasifikasi berbasis objek menggunakan empat nilai similarity tolerance yang berbeda (yaitu 15, 30, 45, dan 60) menghasilkan 24 peta penutup lahan yang berbeda. Gambar 11 menunjukkan beberapa contoh hasil klasifikasi. Semua gambar

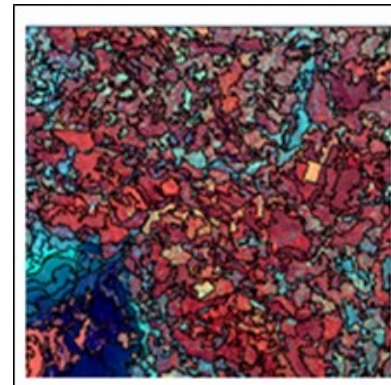

A.CITRA ASLI

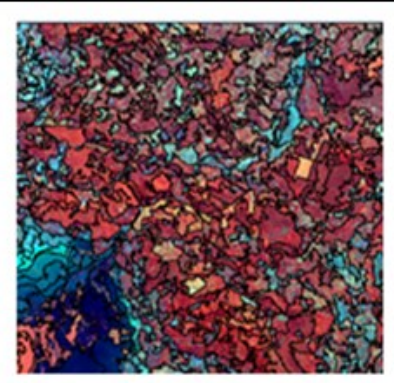

B. TERKOMPRESI LOSSLESS

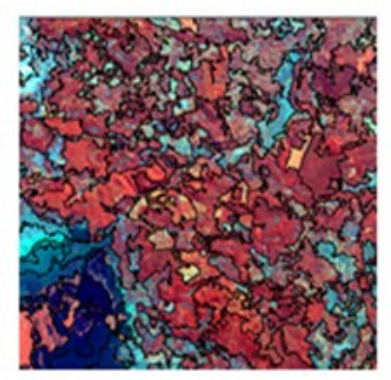

C. TERKOMPRESI KE $50 \%$

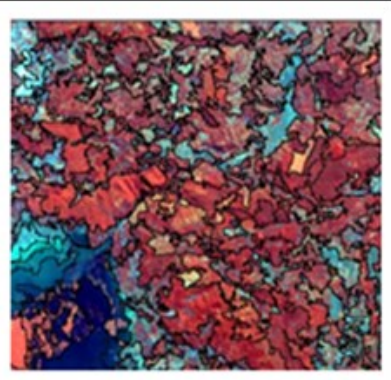

D. TERKOMPRESI KE $10 \%$

Gambar 10. Segmentasi berdasarkan tingkat kompresi yang berbeda, ditampilkan dalam format vektor

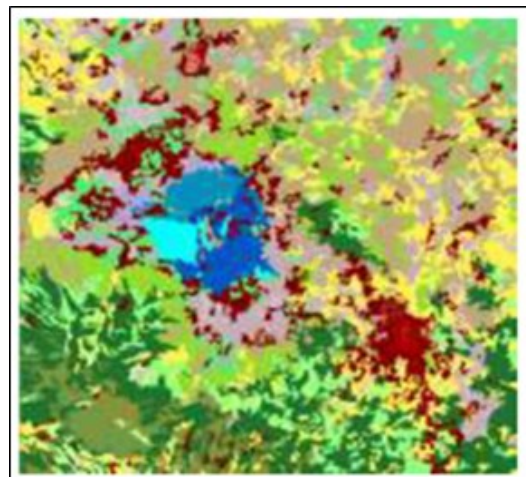

A. CITRA ASLI

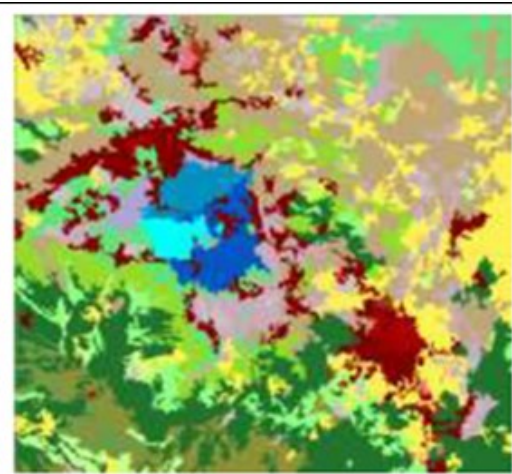

B. CITRA TERKOMPRESI KE-50\%

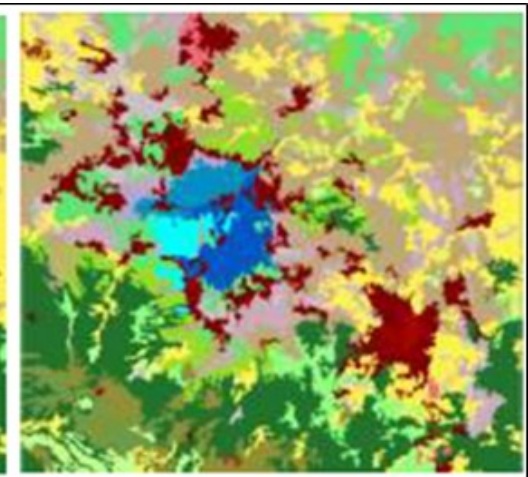

C. CITRA TERKOMPRESI KE-10\%

Gambar 11. Hasil klasifikasi citra berbasis objek menggunakan gambar dengan tingkat kompresi yang berbeda. Similarity tolerance $=30$ 
tersegmentasi dengan menggunakan similarity tolerance $=30$. Evaluasi atas akurasi peta ini dilakukan dengan menggunakan prinsip yang sama dengan metode klasifikasi per piksel yang digunakan. Dataset independen yang sama dalam hal poligon atau ROI yang dikumpulkan berdasarkan pengamatan lapangan dan digambarkan pada citra referensi. Berdasarkan metode evaluasi ini, ditemukan bahwa peta penutup lahan yang dihasilkan dari sub-dataset asli (tidak terkompresi) dengan menggunakan toleransi kesamaan 30 mencapai akurasi keseluruhan tertinggi, yaitu 75,44\%. Gambar 12 berikut menunjukkan efek tingkat kompresi citra yang dikombinasikan dengan similarity tolerance pada hasil klasifikasi berbasis objek ALOS-AVNIR2.

Apabila metode klasifikasi per-piksel dibandingkan dengan metode klasifikasi berbasis objek maka terlihat bahwa klasifikasi berbasis objek memberikan hasil yang relatif konsisten pada berbagai tngkat kompresi, dibandingkan dengan klasifikasi per-piksel. Sebagai bahan perbandingan, digunakan dua hasil terbaik dari klasifikasi per-piksel, yaitu dengan minimum distance to mean dan maximum likelihood yang masing-masing telah mengalami penggabungan kelas; dan dua hasil terbaik dari klasifikasi berbasis objek pada similarity tolerance masing-masing 30 dan 45. Gambar 13 menjelaskan hal ini.

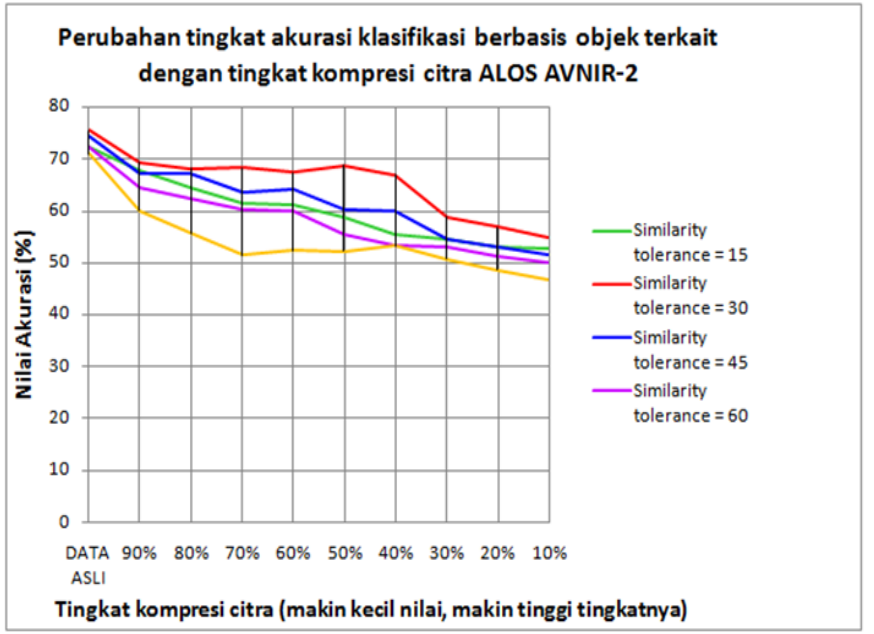

Gambar 12. Perbandingan hasil klasifikasi berbasis objek dengan similarity tolerance yang berbeda-beda, diukur dari tingkat akurasinya..

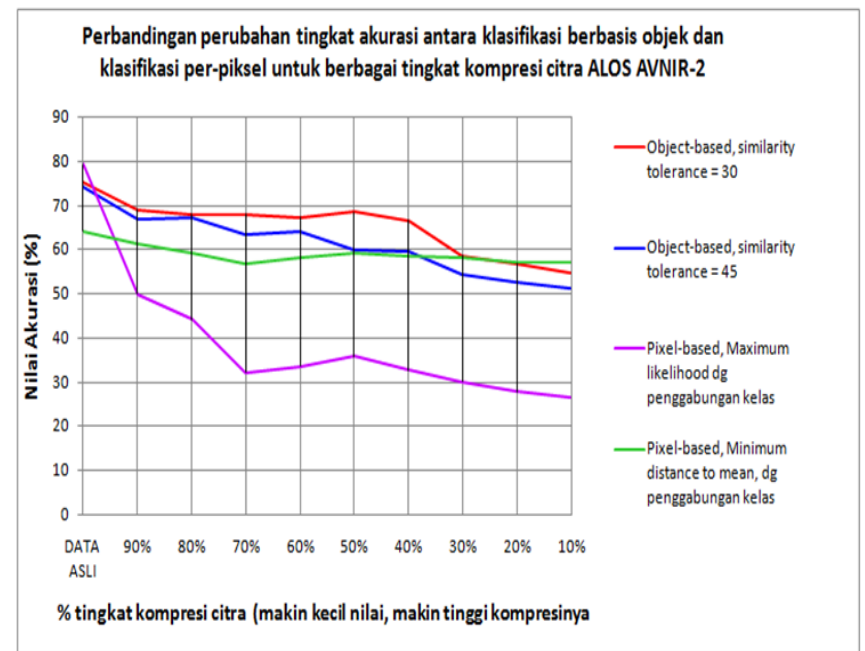

Gambar 13. Perbandingan akurasi yang diperoleh oleh metode klasifikasi per-piksel dan klasifIkasi berbasis objek.

\section{Perbandingan Tiga Metode Ekstraksi Informasi}

Berdasarkan hasil-hasil yang diperoleh dari penggunaan indeks vegetasi, klasifikasi per-piksel, dan klasifikasi berbasis objek, maka hasil terbaik dari masing-masing metode ekstraksi informasi pun kemudian dibandingkan dengan parameter berupa akurasi total dalam persen. Seperti tersaji pada Gambar 14, terlihat bahwa metode indeks vegetasi merupakan metode analisis dan ekstraksi informasi yang paling banyak mengalami penurunan akurasi sejalan dengan meninkatnya kompresi citra. Akurasi estimasi kerapatan vegetasi untuk data asli ALOS AVNIR-2 mencapai lebi dari $80 \%$, tetapi ketika data mulai dikompresi, terlihat bahwa akurasi pun jatuh ke tingkat yang jauh lebih rendah.

Gambar 14 juga menegaskan bahwa citra terkompresi sensitif terhadap semua jenis metode analisis dan ekstraksi informasi otomatis, baik dengan indeks spektral berupa indeks vegetasi, klasifikasi multispektral per-piksel, maupun klasifikasi berbasis objek. Meskipun penelitian ini hanya menggunakan tiga macam formula indeks vegetasi (bandingkan dengan Huete et al., 2002; Dewa dan Danoedoro, 2017, Hidayati et al., 2018b), tiga macam klasifikasi multispektral per piksel yang relatif konvensional (bandingkan dengan Arif et al., 2017), serta klasifikasi berbasis objek yang sederhana (bandingkan misalnya dengan Dragut et al., 2014; Blaschke et al., 2014; Dwiputra et al., 2016), setidaknya hasil yang diberikan telah memberikan gambaran bahwa ketiga metode tersebut tetap dipengaruhi oleh hasil kompresi citra, karena kompresi telah mengubah nilai piksel pada data asli.

\section{KESIMPULAN}

Penelitian ini menegaskan teori bahwa citra digital terkompresi menunjukkan kinerja yang kurang baik apabila diproses untuk ekstraksi informasi otomatis. Meskipun demikian, dari tiga macam metode analisis dan ekstraksi informasi yaitu transformasi indeks vegetasi, klasifikasi multispektral, dan klasifikasi berbasis objek maka klasifikasi berbasis objeklah yang relatif lebih resisten terhadap penurunan kualitas citra akibat kompresi, khususnya pada tingkat kompresi hingga sekitar 50\%. Kajian ini juga menunjukkan bahwa penurunan akurasi terbesar terjadi ketika citra terkompresi diproses dengan transformasi indeks vegetasi.

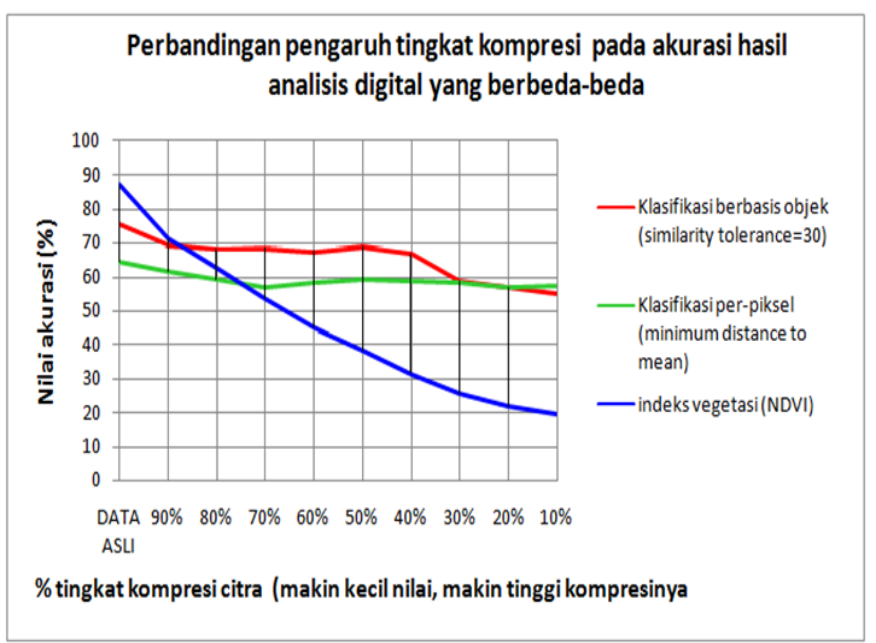

Gambar 14. Hasil perbandingan tiga metode ekstraksi informasi citra ALOS AVNIR-2 secara digital. 


\section{UCAPAN TERIMA KASIH}

Penulis mengucapkan terima kasih pada Japan Aerospace Exploration Agency (JAXA) dan Pusfatja Lapan atas penyediaan citra ALOS AVNIR-2, dan kepada Fakultas Geografi UGM yang telah menyediakan dana hibah dosen untuk penelitian ini.

\section{DAFTAR PUSTAKA}

Al-Janabi, A.A.J. (2015). Ultrafast and Efficient Scalable Image Compression Algorithm. J. ICT Res. Appl. Vol. 9, No. 3, 2015, 214-235.

Aronoff, S. (1990) Geographic Information Systems: A Management Perspective. Ottawa: WL Publications

Arif, N. Danoedoro, P., dan Hartono (2017). Remote Sensing And Gis Approaches To A Qualitative Assessment Of Soil Erosion Risk In Serang Watershed, Kulonprogo, Indonesia. Geoplanning, Vol.4 No.2, $131-142$

Blaschke, T., Hay, G.J., Kelly, M., Lang, S., Hofmann, P. Addink, E. Feitosa, Q.R., van der Meer, F., van der Werff, H., van Coillie, F., and Tiede, D. (2014). Geographic Object-Based Image Analysis - Towards a new paradigm. ISPRS Journal of Photogrammetry and Remote Sensing, Vol 87, January 2014, 180-191. https://doi.org/10.1016/j.isprsjprs.2013.09.014

Cao, C. (1992). Detecting the Scale and Resolution Effects in Remote Sensing and GIS. PhD Dissertation. Louisiana State University

Chouwdury, M. H., and Khatun, A. (2012). Image Compression Using Discrete Wavelet Transform. International Journal of Computer Science Issues, Vol. 9, Issue 4, No 1, July 2012

Chang, K. T. (2017); Introduction to Geographic Informaton Systems. $7^{\text {th }}$ edition. New York: McGraw Hill.

Danoedoro, P. (2006). Extracting Land-Use Information Related to Socio-Economic Function From Quickbird Imagery: A Case Study of Semarang Area, Indonesia. Paper presented at the Map Asia 2006 Conference, Bangkok.

Danoedoro, P. (2009) Land-use Information from the Satellite Imagery: Versatility and Contents for Local Physical Planning. Saarbrucken: Lambert Academic Publishing

Danoedoro, P. (2013). The Effect of Image Compression Level on The Land-Cover Classification Accuracy Of ALOS AVNIR-2 Data Using Per-Pixel And Object-Based Classification. Proceedings of the $34^{\text {th }}$ Asian Conferece on Remote Sensing, Denpasar, Bali,

Danoedoro, P., Kristian, G., dan Rahmi, K.I.N. (2015). Pengaruh metode koreksi radiometrik citra ALOS AVNIR-2 terhadap akurasi hasil estimasi karbon vegetasi tegakan di wilayah kota Semarang bagian timur. Prosiding Pertemuan Ilmiah Tahuan MAPIN ke-20, Bogor.

Danoedoro, P. dan Zukhrufiyati, A. (2015). Integrating Spectral Indices and Geostatistic based on Landsat-8 Imagery For Surface Clay Content Mapping In Gunung Kidul Area, Indonesia. Proceedings oth the $34^{\text {th }}$ Asian Conference on Remote Sensing, Manila, The Philippines.

Danoedoro, P. (2019). Multidimensional Land-use Information for Local Planning and Land Resources Assessment in Indonesia: Classification Scheme for Information Extraction from High-Spatial Resolution Imagery. Indonesian Journal of Geography 51 (2), 131-146

Danoedoro, P., Ananda, I.N., Kartika, C.S.D., Umela, A.F. Indayani, A.B. (2020).Testing a detailed classification scheme for land-cover/ land-use mapping of typical Indonesian landscapes: case study of Sarolangun, Jambi and Salatiga, Central Java. Indonesian Journal of Geography 52 (3), 327 - 340

Dewa, R.P. and Danoedoro, P. (2017). The Effect of Image Radiometric Correction on The Accuracy of Vegetation Canopy Density Estimate Using Several Landsat-8 OLI's Vegetation Indices: A Case Study of Wonosai Area, Gunung Kidul Regency. IOP Conference Series: Earth and Environmental Science, Vol. 54, Issue 1.

Dragut, L., Csililik, O., Eisank, C., and Tiede, D. (2014). Automated Parameterisation for Multi-Scale Image Segmentation on Multiple Layers. ISPRS Journal of Photogrammetry and Remote Sensing, Vol 88, February 2014, 119-127. https://doi.org/10.1016/ j.isprsiprs.2013.11.018

Dwiputra, A.J., Suharyadi, R., dan Danoedoro, P. (2016). Pengaruh Jumlah kelas dan skema Klasifikasi terhadap Akurasi Informasi penggunaan Lahan Hasi Klasifikasi berbasis Objek dengan Teknik Support Vector Machine di Sebagian Kabupaten Kebumen Jawa Tengah. Majalah Geografi Indonesia Vol.29 No.2, pp. 120-133
Eastman, J. R. (2019). Idrisi TerrSet - Guide to GIS and Image Processing. Worcester, MA: Clark Labs, Clark University,

Gao, J. (2010). Digital Analysis of Remotely Sensed Imagery. New York: McGraw Hill.

Ghani, F., Khan, E., and Hami, S. (2000). A Modified JPEG Image Compression Technique. IETE Journal of Research Vol. 46, Issue 5: New Tools in Image Processing, pp 331-337. https:// doi.org/10.1080/03772063.2000.11416174

Hardjo, K.S., Danoedoro, P., dan Zuharnen, (2014). Pendugaan Cadangan Karbon pada Perkebunan Tanaman Teh (Camellia Sinensis) melalui Citra Penginderaan Jauh ALOS AVNIR-2. Majalah Geografi Indonesia Vol. 28 No.1, pp 65-70

Hidayati, I. N. Suharyadi, R. Danoedoro, P. (2018a) Developing an Extraction Method of Urban Built-Up Area Based on Remote Sensing Imagery Transformation Index. Forum Geografi, Vol.32, No.1, pp 96-108

Hidayati, I. N. Suharyadi, R. Danoedoro, P. (2018b). Kombinasi indeks citra untuk analisis lahan terbangun dan vegetasi perkotaan. Majalah Geografi Indonesia, Vol.32, No.1, pp.24-32

Hidayati, I. N. Suharyadi, R. Danoedoro, P. (2018c). Exploring Spectral Index Band and Vegetation Indices for Estimating Vegetation Area. The Indonesian Journal of Geography 50 (2), 211-221

Huete, A., Didan, K., . Miura, T.,. Rodriguez, E.P, Gao, X., and Ferreira, L.G. (2002). Overview of the Radiometric and Biophysical Performance of the MODIS Vegetation Indices. Remote Sensing of Environment No. 83 (2002), $195-213$

Hussain, A. J., Al-Fayadh, Ali., and Radi, N. (2018) Image compression techniques: A survey in lossless and lossy algorithms. Neurocomputing Vol. 300, 44-69. https://doi.org/10.1016/j.neucom.2018.02.094.

Jensen J.R. (2015), Introductory Digital Image Processing. 4th edition. Englewood Cliffs: McGraw Hill

Lillesand, T.M., Kiefer, R.W., and Chipman, J.W. (2014). Remote Sensing and Image Interpretation. $7^{\text {th }}$ edition. New York: John Wiley and Sons.

Mather, P.M. and Koch, M. (2011). Computer Processing of Remotely Sensed Data: An Introduction. London: Wiley

Navulur, K. (2007). Multispectral Image Analysis using the Objectoriented Paradigm. New York: CRC Press

Sulistyo, B., Gunawan, T., Hartono, Danoedoro, P. and Listyaningrum, N. (2017). Absolute Accuracy of the Erosion Model ofDEM-NDVI and it's Modification. International Journal of Geoinformatics Vol. 13/No. 2, pp 23-28

Tan, L., Zeng, Y. and Zhang, W. 2019. Research on Image Compression Coding Technology. IOP Conf. Series: Journal of Physics: Conf. Series 1284 (2019) 012069. IOP Publishing. doi:10.1088/1742$6596 / 1284 / 1 / 012069$

Umarhadi, A.D. and Danoedoro, P. (2020) The Effect of Topographic Correction on Canopy Density Mapping Using Satellite Imagery in Mountainous Area. International Journal on Advance Science, Engineering and Information Technology, Vol.10, No.3, pp.1317 - 1325

Wisnawa, I.G.Y., Sutanto, dan Sudibyakto. (2008). Kemampuan Saluran Termal Citra Landsat 7 Etm+ dan Citra ASTER dalam Memetakan Pola Suhu Permukaan di Kota Denpasar dan Sekitarnya. Majalah Geografi Indonesia. Vol 22, No 1: Maret 2008. 39-51. 